\title{
SELF-EFFICACY AS A PREDICTOR OF THE INDIVIDUAL'S FUTURE LINKS WITH THE EMPLOYING ORGANIZATION
}

\section{AUTOEFICÁCIA COMO PREDITORA DOS VÍNCULOS FUTUROS DO INDIVÍDUO COM A ORGANIZAÇÃO EMPREGADORA}

\author{
Laércio André Gassen Balsan ${ }^{1}$ \\ Antônio Virgílio Bittencourt Bastos ${ }^{2}$ \\ Vânia Medianeira Flores Costa ${ }^{1}$ \\ Marcus Vinicius Nascimento Schleder ${ }^{1}$ \\ Fernanda Binotto Vizzotto Balsan ${ }^{1}$ \\ 1 Universidade Federal de Santa Maria - UFSM, Santa Maria, RS, Brazil \\ 2 Universidade Federal da Bahia - UFBA, Salvador, BA, Brazil
}

\begin{abstract}
Purpose: This study analyzes the influence of the perception of self-efficacy on the commitment, entrenchment, and consent bonds that the individual will establish with the employing organization.

Design/methodology/approach: This is a longitudinal panel-type survey composed of two data collections: one applied before the individual joined the organization, and the other applied nine months after joining the contracting company.

Findings: The main results show the commitment established by individuals, with the contracting organization, can be predicted by the perceived self-efficacy of the individual measured before joining the organization. This suggested that the organization gives preference, at the time of hiring, to individuals with greater self-efficacy, as they will tend to develop higher commitment bond when compared to workers with lower self-efficacy. Besides the dispositional factors, other aspects arising from the individual/organization relationship will be involved in the development of the bond, and will be up to the company's people management team to ensure adequate conditions for the building of a strong affective bond.

Research limitations/implications: To better understand future linkage, other variables need to be tested to verify what are the main antecedents of the future linkage of the individual. A gap left here is the absence of data collection through interviews, which would enrich quantitative data, as well the addition of new variables not tested.

Originality/value: Inserted in the efforts to predict how the new individual's future relationship with the employing institution will be, this study relates self-efficacy to future commitment, entrenchment, and consent, something that does not exist in the literature.
\end{abstract}

Keywords: Self-efficacy. Organizational Commitment. Organizational Entrenchment. Organizational Consent. 


\section{RESUMO}

Finalidade: Este estudo analisa a influência da percepção de autoeficácia sobre os vínculos de comprometimento, entrincheiramento e consentimento que o indivíduo estabelecerá com a organização empregadora. Desenho / metodologia / abordagem: Trata-se de uma survey longitudinal composta por duas coletas de dados: uma aplicada antes do ingresso do indivíduo na organização e outra aplicada nove meses após o ingresso na empresa contratante.

Constatações: Os principais resultados mostram que o comprometimento estabelecido pelos indivíduos, com a organização contratante, pode ser previsto pela percepção de autoeficácia do indivíduo mensurada antes de ingressar na organização. Isso sugere que a organização dá preferência, no momento da contratação, aos indivíduos com maior autoeficácia, pois tendem a desenvolver maior vínculo de comprometimento quando comparados aos trabalhadores com menor autoeficácia. Além dos fatores disposicionais, outros aspectos decorrentes da relação indivíduo / organização estarão envolvidos no desenvolvimento do vínculo, cabendo à equipe de gestão de pessoas da empresa garantir condições adequadas para a construção de um forte vínculo afetivo.

Limitações / implicações da pesquisa: Para melhor compreensão do vínculo futuro, outras variáveis precisam ser testadas para verificar quais são os principais antecedentes do vínculo futuro do indivíduo. Uma lacuna deixada é a ausência de coleta de dados por meio de entrevistas, o que enriqueceria os dados quantitativos, bem como o acréscimo de novas variáveis não testadas.

Originalidade / valor: Inserido no esforço de predizer como será a relação futura do novo indivíduo com a instituição empregadora, este estudo relaciona autoeficácia com comprometimento, entrincheiramento e consentimento futuros, algo inexistente na literatura.

Palavras-chave: Autoeficácia. Comprometimento Organizacional. Entrincheiramento Organizacional. Consentimento Organizacional.

\section{INTRODUCTION}

The bonds established by individuals with the organization are fundamental to understand a series of behaviors favorable to organizational performance (Bastos et al., 2013). There are, therefore, a series of efforts to understand its antecedents and consequences. However, according to Maia (2014), it is rarely sought to understand their formation and dynamics, helping in this understanding is one of the efforts of this work.

The three-dimensional model of bonds with the organization (Commitment, Entrenchment and Consent), proposed by Bastos (2009), Silva (2009), Silva and Bastos (2010), and Rodrigues (2009, 2011 ) is worked here, in which commitment involves the active contribution, extra effort, and commitment of the individual. This represents the central core of the definition of affective commitment as brought by Meyer and Allen in 1991.

Entrenchment is a form of protection, safety, stability, maintaining status quo, and avoiding other losses associated with your exit. In this context, the bond established between individual and organization does not include desire, but a need (Rodrigues, 2009, 2011).

The concept of organizational consent indicates the bias of the individual to obey the superior due to the perception that the boss knows better what to do, as well the power relations established among manager and subordinate (Silva \& Bastos, 2010).

The personal and organizational factors that influence the development of entrenchment and consent bonds can be explained by common factors that are similar to each other, but they differ from commitment. These differences reinforce the need for a better understanding of the development and formation of the individual's link with the organization. 
Inserted in the efforts to predict how the new individual's future relationship with the employing institution will be, this study relates self-efficacy to future commitment, entrenchment, and consent, something that does not exist in the literature. The inclusion of self-efficacy in this study as a predictor of future bonds is based on the conceptualization of Lee et al. (1992), who, considering the importance of self-efficacy, composed their instrument of measurement of propensity to the commitment with the inclusion of seven items that measured self-efficacy.

Meyer et al. (2002), in their meta-analysis, had also observed the positive relationship between self-efficacy and organizational commitment. Pillai and Williams (2004) also suggested that perceptions of self-efficacy play an important role in increasing commitment. That is, individuals who have an individual perception of their ability to succeed in different situations (Judge, Erez, \& Bono, 1998; Chen, Gully, \& Eden, 2001) would be more committed. This statement is corroborated by empirical studies that demonstrate a positive relationship between self-efficacy and organizational commitment (Judge et al., 1999; Bzuneck \& Guimarães, 2003; Luthans; Zhu;\& Avolio, 2006; Salami, 2007; Rathi \& Rastogi, 2009; Yousaf, Tsai, Tsai,\& Wang, 2011; Sanders, 2012; Garcia, 2015; Ahmed, 2019; Orgambídez et al., 2019).

Based on the above, there is a gap to be filled, namely: What is the influence of perceived self-efficacy on the bonds that the individual will establish with the employing organization? To answer the research question, this study aims to analyze the influence of the perception of self-efficacy on the commitment, entrenchment, and consent bonds that the employee will establish with the organization. To this end, a longitudinal study was conducted, which comprised two data collections: one before the individual joined the organization and another nine months after starting the new job, conducted in eleven companies located in two Brazilian states.

\section{ORGANIZATIONAL COMMITMENT, ENTRENCHMENT, AND CONSENT}

Throughout life, the individual develops various bonds with people, groups, and organizations. Specifically with the organization, bonds of commitment, entrenchment, and consent can be developed.

Until mid-2009, before the definition of Organizational Entrenchment and Consent, there was a stretching of the concept of commitment resulting from the inclusion of active and passive dimensions. According to Bastos et al. (2013), this fact was due to the concern of managers to retain their workers and reduce turnover in organizations. The author states that commitment is a positive bond that supports pro-social behaviors by promoting actions that go beyond what is prescribed by the position.

The commitment represents an affective bond, which should not be understood as a force that presses the individual, but rather a bond that binds them to the organization. According to Bastos (2009) and Rodrigues (2009) commitment is not the abidance by need, by obligation; it is not continuation in the course of action due to loss of investment or personal sacrifice, in case of changes; nor is commitment to stay in the job due to the lack of other job options. These factors are understood as bonds established between the professional and the organization, but do not integrate the concept of organizational commitment, in fact they integrate the Organizational Entrenchment construct.

The entrenched professional stays in the organization out of necessity rather than willingness, due to liking it. The individual designs in the company a way to protect themselves, to feel safe, because they have stability and social status. So, entrenched workers sense that their departure from the organization will cause serious damage to them, and therefore they remain working, not because they want to contribute to the growth of the company (Rodrigues, 2009; Bastos, 2009). 
Rodrigues (2011) explains that the organizational entrenchment construct is composed of the factors "adjustments to social position," "impersonal bureaucratic arrangements," and "limitation of alternatives".

Adjustments to social position: Both the professional and the organization make investments so that a certain activity is well developed. Rodrigues (2009) exemplifies the adjustments as training to improve certain jobs, which could cause, over time, the feeling that all that was learned and trained in recent years would be focused on the specific activities developed in that organization. Still, the position achieved in the company would influence the attitudes taken and the established professional contacts, making the individual be recognized for their performance and their role in the organization, which would be lost if the worker left the company.

Impersonal bureaucratic arrangements: It is the permissibility of a situation due to the practicalities involved. The professional fears, with the change of professional activity, losing the stability obtained, the financial gains, and the benefits acquired, such as health and dental insurance plans, pension, retirement, among others (Ibidem).

Limitation of alternatives: the individual has the feeling of being entrenched in the company due to the absence of alternatives, as they verify that there is no space in the labor market, their age is not within the professional parameter sought by other companies, their knowledge would not be adequate or enough to work in another organization and therefore they would not be accepted in another job (Ibidem). Likewise, commitment is not linked to activities in accordance with company standards or obedience to superiors, revealing a "passive" attitude towards the organization (Organizational Consent) (Silva \& Bastos, 2010).

Organizational Consent is based on a sense of obligation, duty, and loyalty to the organization. The nature of this bond leads to the idea that the individual must be a worker who complies with company standards, follows what is established, and consequently passively obeys the superiors (Silva \& Bastos, 2010).

The concept is a link without reference to the affective aspects, privileging, exclusively, the subordination relationship that is established between the superior and the employee, being coordinated by the social roles assumed by the subjects.

Assuming that "being subordinate" is an inherent condition of the worker role, as well the existence of normative codes that specify morally correct ways of domination, Silva (2009) conceptualizes consent as based on the meaning of acquiescence, which means to consent, to assent, to agree or to concede.

The operational definition of the construct states it as the tendency of the individual to obey the superior, which represents the organization in which the worker is employed. By obeying, the worker consents to the fulfillment of orders due to authority relationships established through the hierarchy, as well the perception that the boss knows better what should be done (Silva \& Bastos, 2015).

\section{SELF-EFFICACY}

The self-efficacy construct was proposed by Bandura, in 1977, from clinical studies in which he sought to treat people with severe phobias using social modeling and self-regulation.

The concept of self-efficacy is linked to the Cognitive Social Theory (Azzi \& Polydoro, 2006) and it is initially defined as the belief that people develop about their personal abilities to successfully initiate, carry out, and perform specific tasks that may require effort and perseverance in the face of adversities. Thus, according to Bandura (1977), the concept is linked to the possibility of behavior modification through a change in the individual's perception of their capacity and how changes can occur. That is, it is a belief of the subjects in their ability to produce desired effects through their actions. 
This concept comprises the person as an active agent, who not only reacts to circumstances but also acts to control them (Shinyashiki, 2006). According to Wood and Bandura (1989), and Martínez and Salanova (2006), it is no use having skills and being able to use them. For the successful achievement of goals beyond the necessary skills, the individual must believe in their ability to use them. That is, for authors, people with the same skills may have different performances according to their self-efficacy perception.

The stronger the perception of self-efficacy the more vigorous and persistent will be the effort, and it is an important system for the individual to achieve the goals and successfully perform the tasks they have set to themselves (Wood \& Bandura, 1989; Schwarzer, 1992; Bandura, 1982, 2001, 2002; Zimmerman, 2000; Bandura; Locke, 2003).

There are some concepts very similar to self-efficacy, witch can be confused with each other. Self-efficacy is distinguished from self-concept, self-esteem, and locus of control in three central aspects: (a) self-efficacy implies an internal attribution (the individual is the cause of action); (b) it is prospective, while having implications for future behaviors; and (c) it is an operative construct, being a good predictor of current behavior (Schwarzer \& Hallum; 2008).

For Pajares and Olaz (2008), self-efficacy beliefs are cognitive judgments of competence oriented to a future task, and it is different from the self-concept that, according to Martínez and Salanova (2006), represents the individual's view of themselves.

Similarly, while self-efficacy reflects an individual's assessment of themselves, in which there is a sense of acceptance or denial about their way of being, their qualities, and defects (Gist \& Mitchell, 1992; Barros \& Batista-Dos-Santos, 2010). Self-efficacy refers to the perceived ability to perform tasks being cognitively predominant (Gist \& Mitchell, 1992). For Chen, Gully, and Eden (2004), what distinguishes self-esteem from self-efficacy is the affective emphasis of the former as opposed to the motivational emphasis of the latter, when compared with each other. Researches on the relationships between employee self-efficacy, involvement and satisfaction beliefs has been largely based on cross-sectional data (Zee \& Koomen, 2016).

Bandura (2008) teaches that self-efficacy also differs from the locus of control, which is the way the individual is responsible for the results of their actions. That is, the individual can consider the results obtained from their behavior or external forces.

Given the differentiation between self-referential constructs, the great importance of self-efficacy for research is reinforced, as it predicts: professional performance (Gist, 1987; Schwazner, 1992; Stajkovic \& Luthans, 1998; Lubbers, Loughlin \& Zweig, 2005; Latham \& Pinder, 2005; Barros; Batista-Dos-Santos, 2010), satisfaction (Judge et al. 2005; Caprara et al., 2006; Perdue et al., 2007; Canrinus et al., 2012), organizational commitment (Bzuneck \& Guimarães, 2003; Yousaf \& Sanders, 2012; Tsai, Tsai, \& Wang, 2011), occupational (Rots et al., 2007, Chan et al., 2008; Canrinus et al., 2012) among others.

\section{METHOD}

A longitudinal panel-type survey was performed (Babbie, 2005; Smith \& Young, 2019). Two structured questionnaires were applied to the same individuals: one applied before the individual joined the organization, and the other applied nine months after joining the contracting company.

The second collection was set to 9 months after the beginning of the first one so that there would be a lapse of time so that there was no individual experiencing the period called "honeymoon." That is, that period that follows the hiring of the individual, which is characterized by fascination, enthusiasm, euphoria, optimism (Fichman \& Levinthal, 1991; Boswell et al., 2005; Chang \& Choi, 2007; Jokisaari \& Nurmi, 2009; Solinger et al., 2013) and the high commitment to the organ- 
ization (Chang \& Choi, 2007), resulting from this initial excitement, which can last from a few days to 6 months (Chang \& Choi, 2007; Jokisaari \& Nurmi, 2009). Such initial excitement could bias the results of this study.

To carry out the first collection, the research instrument was applied directly in print to individuals during the training courses, or in a place defined according to the convenience of each individual. The questionnaires were applied to subjects who agreed to participate in the research when they received an explanation of the study objectives, ethical standards, data confidentiality, data treatment, and the availability of results.

For the second collection, we chose the digital version of the questionnaire, which was applied through the online tool Survey Monkey.

In the first collection, which occurred before the individuals' joined the institution, questionnaire number 1 (one) was applied to collect the individual's sociodemographic and their self-efficacy data.

Self-efficacy was measured by the New General Self-Efficacy Scale created by Chen, Gully, and Eden (2001) and subsequently validated to the Brazilian context by Balsan et al. (in press). The validated scale is one-dimensional, composed of 6 items, and it has internal consistency.

In the second collection, the Organizational Commitment scales (Bastos \& Aguiar, 2015), the Organizational Entrenchment measure (Rodrigues \& Bastos, 2015), and the Organizational Consent scale (Silva \& Bastos, 2015) were applied.

To measure the measurement items of the constructs, a five-point Likert scale was used, where the assignment of number 1 (one) represents "Strongly Disagree" and number 5 (five), "Strongly Agree."

After defining the scales, the instruments were pre-tested to eliminate possible defects. It is important to emphasize that the pre-test data were not considered in the sample. This step aimed to verify the possible inconsistencies (complexity of the questions, inaccuracy in the wording, unnecessary questions, an embarrassment to the informant, exhaustion, among others) that the data collection instrument could present, and thus identify possible improvements.

Due to the impossibility of obtaining a random probabilistic sample, the sampling procedure chosen was the non-probabilistic one. The sample was intentional, aiming to find people able to respond to the problem proposed in this research (individuals joining the organization).

The collection took place in public and private companies from various segments, located in two Brazilian states: Rio Grande do Sul and Bahia (one from the south and one from the northeast of Brazil). Data were collected from eleven companies, four public (hospital, legal advice, municipal executive and Higher Education Institution) and seven private companies (geoprocessing, technology, service provision, Higher Education Institution, restaurant, food distribution sectors and information technology), totaling 504 research participants.

The process of data analysis began with descriptive and exploratory analyses to investigate the accuracy of data entry; the distribution of missing cases; the description of the sample; the extreme cases and the distribution of the variables. Subsequently, Cronbach's Alpha internal consistency indicator was used to verify the reliability of the theoretical constructs used in the questionnaire.

Simple descriptive analyses were performed (frequencies, means, and standard deviations) and verification of correlations between constructs (Spearman correlation). In the tests, differences that represented a $p<0.05$ were considered statistically significant. A study was conducted by linear regression, aiming to reach models of the influence of self-efficacy on the individual's links with the organization. 


\section{RESULTS}

Regarding the profile of the research participants, there was a larger number of women in the sample (67.7\%). The average age is 32.47 years, ranging between 18 and 59 years old. As for education, the predominance is concentrated in undergraduate $(25.7 \%)$, specialization $(28.1 \%)$, high school (29.1\%), and master's degree ( $8.4 \%$ ) levels. Out of the total respondents, half are single (49.7\%). Most participants are Catholics (53.1\%), followed by Protestants (20.9\%), Spiritists (12.5\%), and Umbanda (1.7\%).

A Cronbach's alpha was obtained for the Self-efficacy measure equal to 0.785 . Which is considered a good index by Hair et al. (2009). The alpha obtained on the Entrenchment scale was 0.863. We highlight the excellent degree extracted for the Organizational Commitment $(\alpha=0.931$ ) and Organizational Consent $(\alpha=0.904)$ scales.

To identify the levels of linkage, three distinct categories were agreed upon: High (mean from $66.67 \%$ to $100 \%$ ), Medium (mean from $33.33 \%$ to $66.67 \%$ ), and Low (mean from 0 to $33.33 \%$ ). The results show that the individuals researched present, on average, a greater commitment (3.75) than consent (3.02) and entrenchment (2.48). Organizational entrenchment presented means categorized as moderate for its dimensions adjustment to the social position (2.47), limitations of alternatives (1.89), and impersonal bureaucratic arrangements (3.06). Consent was also at a moderate level.

Regarding the Self-efficacy construct, the findings indicate a high level (3.88). Overall, standard deviations were low, indicating little response variability. To identify the influence of Self-efficacy as a possible antecedent of the Organizational Commitment, Entrenchment, and Consent built by the individual after joining the workplace, the data were first analyzed using the Spearman correlation coefficient and then linear regression. The correlations between the constructs are displayed in Table 1.

Table 1 - Correlation Matrix between Constructs

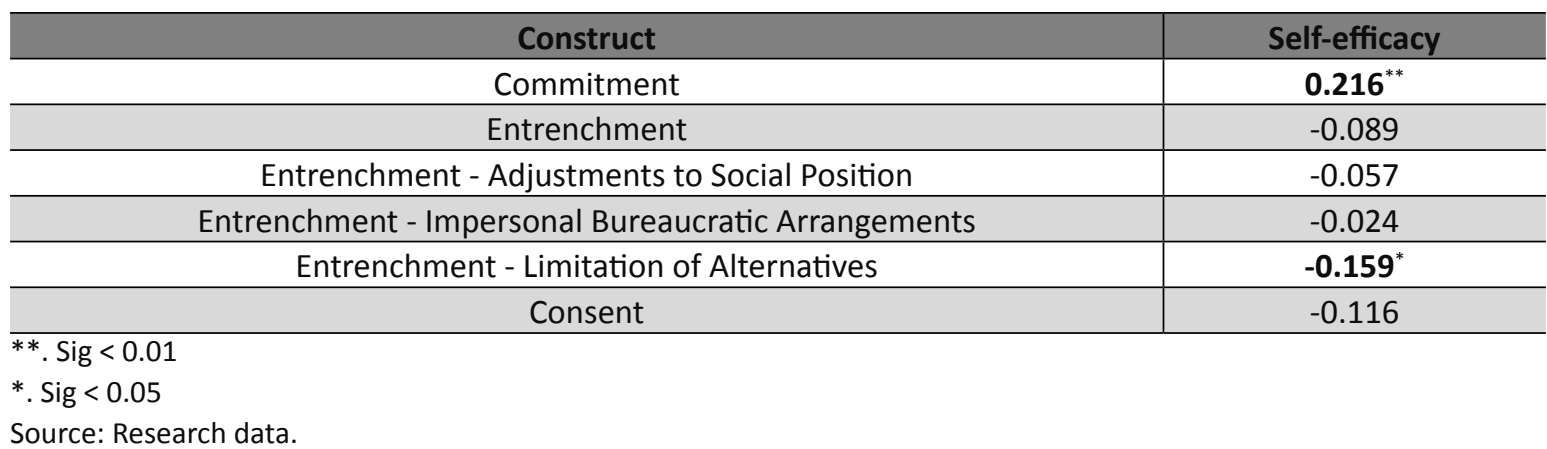

When analyzing the data, it was observed that self-efficacy was negatively correlated with the Entrenchment limitation of alternatives factor $(-0.159, \mathrm{p}<0.05)$ and positive with Organizational Commitment (0.216, p0.01). Meyer et al. (2002), in their meta-analysis, had also observed the positive relationship between self-efficacy and organizational commitment. Pillai and Williams (2004) and Fatieh (2011) also suggested that perceptions of self-efficacy play an important role in increasing commitment. These studies compared self-efficacy with commitment to a cross-section measurement.

The result suggests that higher levels of self-efficacy measured before the individual joined the organization are associated with a higher level of future commitment to the employing organization. In constrast, self-efficacy is a construct inversely related to Limitations of Alternatives. Therefore, corroborating with Judge, Erez, and Bono (1998) and Chen, Gully, and Eden (2001), individuals who have an individual perception of their ability to succeed in different situations perceive a better employability. In practical terms, individuals who can perform their tasks and achieve their goals 
tend to stay in the organization not because they perceive limitations of alternatives, but because they have a greater emotional bond with it.

This statement is corroborated by empirical studies that demonstrate a positive relationship between self-efficacy and organizational commitment (Judge et al., 1999; Bzuneck \& Guimarães, 2003; Luthans, Zhu, \& Avolio, 2006; Salami, 2007; Rathi \& Rastogi, 2009; Vohra \& Goel, 2009; Yousaf \& Sanders, 2012; Tsai, Tsai; \& Wang, 2011; Rainayee, Zaffar, \& 2012; Garcia, 2015; Ahmed, 2019; Orgambídez et al., 2019).

To verify the relationship (cause-effect) of the perception of self-efficacy on the organizational commitment, entrenchment, and consent variables, the intention was to formulate regression models that were significant and representative. Several tests were performed changing the dependent variable (commitment; entrenchment and its dimensions; and organizational consent) and maintaining the independent variable (self-efficacy).

When confronting the influence ratio of self-efficacy on organizational commitment, the value of the F statistic was significant, which leads to the rejection of nullity of the independent variable parameter coefficients, proving that it is unlikely that the results were obtained by a sampling error.

The adjusted $R^{2}$ indicated that the independent variable could explain around $3.9 \%$ of the variance of the commitment variable measured 9 months after the individual joined the employing organization.

To verify the independence of the regression residues, the Durbin Watson Test was performed. For the proposed models, the assumption of no autocorrelation of residues was met, which, according to Gujarati (2011), at a level of $1 \%$ of significance, they should have values ranging from 1.63 to 2.37 for a sample with more than 200 cases.

After performing the statistical analyses to verify the adequacy of the regression model assumptions, their coefficients are presented in Table 2 .

Table 2 - Coefficients

\begin{tabular}{|c|c|c|c|c|c|c|}
\hline \multirow{2}{*}{ Model } & \multicolumn{2}{|c|}{ Non-standardized Coefficients } & Standardized Coefficients & \multirow{2}{*}{ T } & \multirow{2}{*}{ Sig. } \\
\cline { 2 - 5 } & B & Standard error & Beta & & \\
\hline \multirow{2}{*}{1} & constant & 2.584 & .391 & & 6.612 & .000 \\
\cline { 2 - 7 } & Self-efficacy & .292 & .094 & .209 & 3.115 & .002 \\
\hline
\end{tabular}

Source: Research data.

In this regression calculation, the values of TOL and VIF (VIF $<10$ and TOL $>0.1$ ) were adequate, not indicating multicollinearity problems (HAIR et al., 2009). The Regression Model found can thus be defined: $Y=2.584+0.292 . X$, where $Y=$ organizational commitment and $X=$ self-efficacy.

The results suggest that the organizational commitment variable increases with the increasing of perceived self-efficacy. In terms of standardized variables, the final model is given by: COMMITMENT $=0.209$.SELF-EFFICACY. Seen in these terms, it is clear that the adjusted coefficient of determination values demonstrated that self-efficacy contributes to explain the individual's future commitment to the organization. So, in practical terms, when wanting more committed employees, it is suggested that the organization gives preference, at the time of hiring, to individuals with greater self-efficacy, as they tended to develop a higher commitment bond when compared to workers who have lower self-efficacy.

The relationships of influence of self-efficacy on other links and the Limitation of Alternatives factor of Organizational Entrenchment presented solutions for the F Test without statistical significance. That is, rejecting the null hypothesis shows that models adding the self-efficacy predictor are no better than models without the predictor (FIELD, 2009). Given this, it was not possible 
to establish a regression model with a better prediction than using the mean value obtained by the linkage variables, since self-efficacy is not useful in predicting future values of Organizational Entrenchment and Consent.

\section{FINAL CONSIDERATIONS}

This study is part of efforts to identify which prior characteristics the individual brings with them into the organization that made them more committed, entrenched, or consented. More specifically, it aimed to analyze the influence of the perception of self-efficacy measured before the individual joined the organization on the future links of organizational commitment, entrenchment, and consent, something that has not been attempted by academia to date, especially with regard to the Entrenchment and Consent constructs given their novelty in the scientific field.

We do not discard possible insights and comparative transpositions between the entrenchment and consent links and the instrumental and normative commitments, which even though conceptually different, may indicate hypotheses to be tested given the similarity of behaviors.

Going further, new elements are added so that organizations can select the desired profile when hiring new employees.

Regarding the level obtained by the respondents in each variable, it was found that individuals 9 months after joining the organization, showed a high level of organizational commitment, indicating that most employees are willing to exert effort on behalf of the organization in which they work. Besides Organizational Commitment, Entrenchment, and Consent were analyzed, which were moderately presented. That is, individuals do not see major costs associated with leaving, or they may believe there are costs, but they see other work opportunities that are compensatory.

It is important to emphasize that the entrenchment extremes (excessive mobility versus very low mobility) are not interesting to the company. This is because high mobility affects organizational learning and, as a consequence, the competitiveness of the organization. On the other hand, levels of Consent indicate that individuals have a certain passivity towards the organization, complying with most of the standards and respecting hierarchical superiors.

This research linked and related the studied variables and presented the role of the self-efficacy variable as a predictor of future links developed by the individual with the organization. In this line of reasoning, correlation analyzes show that people with a high level of self-efficacy tend to have a higher level of Commitment and a lower level of limitations of alternatives.

Seeking to verify the relationship (cause-effect) of self-efficacy on organizational commitment, organizational entrenchment, and organizational consent, the objective was to find regression models that were significant and representative. Several tests were performed, changing the dependent variable (Organizational Commitment, Consent, and Entrenchment) and maintaining the independent variable (Self-efficacy). From these relationships, only the regression model that supported the influence of self-efficacy on organizational commitment proved to be valid.

Seen in these terms, it is clear that the adjusted coefficient of determination values demonstrated that self-efficacy contributes to explain the individual's future commitment to the organization. Thus, when wanting more committed employees, it is suggested that the organization gives preference, at the time of hiring, to individuals with higher self-efficacy because they tended to develop a higher commitment bond when compared to workers with lower self-efficacy, even with the low explanatory power of the regression model, which can explain around $3.9 \%$ of the organizational commitment variance with a beta equal to 0.209 . 
From a practical point of view, this explains very little of the variation in commitment. However, as the individual's link depends on different factors, the explanatory power of self-efficacy on commitment, mainly because it is a psychological issue, depends on multiple variables, thus reducing its prediction. Besides, other factors arising from the individual-organization relationship will be involved in the development of the bond, and it will be up to the company's Human Resources team to ensure adequate conditions for building a strong affective bond.

The self-efficacy influence relationships on the other links presented solutions for the $F$ Test without statistical significance. Theoretically, it was believed that individuals with higher self-efficacy would tend to have a lower entrenchment bond as they feel more capable and competent, which would lead them to believe that they would have greater work alternatives and fewer sacrifices to qualify and change the job or company. This fact was not true in the regressions, despite the negative correlation between self-efficacy and the limitation of alternatives factor of Organizational Entrenchment.

The present study brings a new possibility to better understand future linkage, so it does not end here, as stated, other variables need to be tested to verify what are the main antecedents of the future linkage of the individual. It is emphasized the importance of new investigations involving the theme, mainly because it is a new subject and extremely important for the recruitment and selection processes.

A gap left here is the absence of data collection through interviews, which would enrich quantitative data. Thus, new directions are needed, as well the addition of new variables not tested here. 


\section{REFERENCES}

Ahmed, N.O.A. (2019), Career commitment: the role of self-efficacy, career satisfaction and organizational commitment, World Journal of Entrepreneurship, Management and Sustainable Development, just-accepted, pp. 00 - 00.

Azzi, R. G.; Polydoro, S. (2006). Autoeficácia proposta por Albert Bandura. In Azzi, R. G.; Polydoro, S. (Eds.), Autoeficácia em diferentes contextos (pp. 9-23). Campinas, SP: Alínea.

Babbie, E. (2005). Métodos de Pesquisa de Survey. Belo Horizonte, MG: UFMG.

Balsan, L. A. G.; Carneiro, L. L.; Bastos, A. V. B.; Costa, V. M. C. (in press). Adaptação e validação da nova Escala Geral de Autoeficácia. Revista Avaliação Psicológica.

Bandura, A. (1977). Self-efficacy: toward a unifying theory of behavioral change. Psychological Review, 84(2), 191-215.

Bandura, A. (1982). Self-efficacy mechanism in human agency. American Psychologist, 37(2), 122-147.

Bandura, A. (2001). Social cognitive theory: an agentic perspective. Annual Review of Psychology, 52, 1-26.

Bandura, A. (2002). Social cognitive theory in cultural context. Journal of Applied Psychology: An International Review, 51(2), 269-290.

Bandura, A. (2008). A evolução da teoria social cognitiva. In Bandura, A.; Azzi, R. G.; Polydoro, S. A. J. (Eds.), Teoria social cognitiva: conceitos básicos (pp. 15-41). Porto Alegre, RS: Artmed.

Bandura, A.; Locke, E. A. (2003). Negative Self-Efficacy and Goal Effects Revisited. Journal of Applied Psychology, 88(1), 87-99.

Barros, M.; Batista-Dos-Santos, A. C. (2010). Por dentro da autoeficácia: um estudo sobre seus fundamentos teóricos, suas fontes e conceitos correlatos. Revista Espaço Acadêmico, 112.

Bastos, A. V. B. (2009). Comprometimento, consentimento ou entrincheiramento. Um estudo comparativo entre categorias ocupacionais e contextos organizacionais. Relatório final apresentado ao CNPQ. Bahia: Salvador, 3240.

Bastos, A. V. B. et al. (2013). Comprometimento no trabalho: fundamentos para a gestão de pessoas. In Borges, L. O.; Mourão, L. O trabalho e as organizações: atuações a partir da psicologia (pp. 279-310). Porto Alegre, RS: Artmed.

Bastos, A. V. B., Rodrigues, A. C. A., Brito, A. P. M. P., \& Silva, E. E. C. E. (2008). Os vínculos do indivíduo com a sua organização empregadora: questões conceituais que cercam as medidas existentes. In III Congresso Brasileiro de Psicologia Organizacional e do Trabalho.

Bastos, A. V. B.; Aguiar, C. V. N. Comprometimento Organizacional. (2015). In Puente-Palacios, K.; Peixoto, A. L. A. Ferramentas de diagnóstico para organizações e trabalho: um olhar a partir da psicologia (pp. 78-91). Porto Alegre, RS: Artmed.

Boswell, W. R., Boudreau, J. W., \& Tichy, J. (2005). The relationship between employee job change and job satisfaction: the honeymoon-hangover effect. Journal of applied psychology, 90(5), 882-892. 
Bzuneck, J. A., \& Guimarães, S. É. R. (2003). Crenças de eficácia de professores: validação da escala de Woolfolk e Hoy. Psico-USF, 8(2), 137-143.

Canrinus, E. T., Helms-Lorenz, M., Beijaard, D., Buitink, J., \& Hofman, A. (2012). Self-efficacy, job satisfaction, motivation and commitment: Exploring the relationships between indicators of teachers' professional identity. European journal of psychology of education, 27(1), 115-132.

Caprara, G. V., Barbaranelli, C., Steca, P., \& Malone, P. S. (2006). Teachers' self-efficacy beliefs as determinants of job satisfaction and students' academic achievement: A study at the school level. Journal of school psychology, 44(6), 473-490.

Chan, W. Y., Lau, S., Nie, Y., Lim, S., \& Hogan, D. (2008). Organizational and personal predictors of teacher commitment: The mediating role of teacher efficacy and identification with school. American educational research journal, 45(3), 597-630.

Chang, J. Y., \& Choi, J. N. (2007). The dynamic relation between organizational and professional commitment of highly educated research and development (R\&D) professionals. The Journal of social psychology, 147(3), 299-315.

Chen, G., Gully, S. M., \& Eden, D. (2001). Validation of a new general self-efficacy scale. Organizational research methods, 4(1), 62-83.

Fichman, M., \& Levinthal, D. A. (1991). Honeymoons and the liability of adolescence: A new perspective on duration dependence in social and organizational relationships. Academy of Management review, 16(2), 442-468.

Field, A. (2009). Descobrindo a estatística usando o SPSS. Porto Alegre, RS: Artmed.

Garcia, Gilbert F., "The Relationship Between Self-Efficacy and Employee Commitment Among Perfusionists" (2015). Walden Dissertations and Doctoral Studies. 1309.

Gist, M. E. (1987). Self-efficacy: Implications for organizational behavior and human resource management. Academy of management review, 12(3), 472-485.

Gist, M. E., \& Mitchell, T. R. (1992). Self-efficacy: A theoretical analysis of its determinants and malleability. Academy of Management review, 17(2), 183-211.

Gujarati, D. (2011). Econometria Básica. Rio de Janeiro, RS: Elsevier.

Hair, J. F., Black, W. C., Babin, B. J., Anderson, R. E., \& Tatham, R. L. (2009). Análise multivariada de dados. Bookman editora.

Jokisaari, M., \& Nurmi, J. E. (2009). Change in newcomers' supervisor support and socialization outcomes after organizational entry. Academy of Management Journal, 52(3), 527-544.

Judge, T. A., Bono, J. E., Erez, A., \& Locke, E. A. (2005). Core self-evaluations and job and life satisfaction: the role of self-concordance and goal attainment. Journal of applied psychology, 90(2), 257.

Judge, T. A., Erez, A., \& Bono, J. E. (1998). The power of being positive: The relation between positive self-concept and job performance. Human performance, 11(2-3), 167-187.

Judge, T. A., Thoresen, C. J., Pucik, V., \& Welbourne, T. M. (1999). Managerial coping with organizational change: A dispositional perspective. Journal of applied psychology, 84(1), 107-122. 
Klein, H. J., Molloy, J. C., \& Cooper, J. T. (2009). Conceptual foundations: Construct definitions and theoretical representations of workplace commitments. Commitment in organizations: Accumulated wisdom and new directions, 1, 3-36.

Latham, G. P., \& Pinder, C. C. (2005). Work motivation theory and research at the dawn of the twentyfirst century. Annu. Rev. Psychol., 56, 485-516.

Lee, T. W., Ashford, S. J., Walsh, J. P., \& Mowday, R. T. (1992). Commitment propensity, organizational commitment, and voluntary turnover: A longitudinal study of organizational entry processes. Journal of management, 18(1), 15-32.

Lubbers, R., Loughlin, C., \& Zweig, D. (2005). Young workers' job self-efficacy and affect: Pathways to health and performance. Journal of Vocational Behavior, 67(2), 199-214.

Luthans, F., Zhu, W., \& Avolio, B. J. (2006). The impact of efficacy on work attitudes across cultures. Journal of World Business, 41(2), 121-132.

Maia, L. G. (2014). Organizational commitment, psychological contract and job performance: $A$ longitudinal study with newcomers, Salvador, BA: Universidade Federal da Bahia.

Meyer, J. P., \& Allen, N. J. (1991). A three-component conceptualization of organizational commitment. Human resource management review, 1(1), 61-89.

Meyer, J. P., Stanley, D. J., Herscovitch, L., \& Topolnytsky, L. (2002). Affective, continuance, and normative commitment to the organization: A meta-analysis of antecedents, correlates, and consequences. Journal of vocational behavior, 61(1), 20-52.

Orgambídez, A., Borrego, Y., \& Vázquez-Aguado, O. (2019). Self-efficacy and organizational commitment among Spanish nurses: the role of work engagement. International nursing review, 66(3), 381-388.

Pajares, F., \& Olaz, F. (2008). Teoria social cognitiva e auto-eficácia: uma visão geral. Teoria social cognitiva: conceitos básicos. Porto Alegre, RS: Artmed, 97-114.

Perdue, S. V., Reardon, R. C., \& Peterson, G. W. (2007). Person-environment congruence, self-efficacy, and environmental identity in relation to job satisfaction: A career decision theory perspective. Journal of employment counseling, 44(1), 29-39.

Pillai, R., \& Williams, E. A. (2004). Transformational leadership, self-efficacy, group cohesiveness, commitment, and performance. Journal of organizational change management. 17(2), 144159.

Rainayee, R. A., \& Zaffar, S. (2012). Relationship between self-efficacy and organizational commitment (A conceptual framework). International Journal of Information Business \& Management, 4(3), 100-115.

Rathi, N., \& Rastogi, R. (2009). Assessing the relationship between emotional intelligence, occupational self-efficacy and organizational commitment. Journal of the Indian Academy of Applied Psychology, 35(1), 93-102.

Rodrigues, A. C. D. A. (2011). Trabalhador entrincheirado ou comprometido? Delimitação dos vínculos do indivíduo com a organização. Salvador, BA: UFBA. 
Rodrigues, A. C. D. A., \& Bastos, A. V. B. (2015). Entrincheiramento organizacional. In Puente-Palacios, K., \& Peixoto, A. D. L. A, Ferramentas de diagnóstico para organizações e trabalho: um olhar a partir da psicologia (pp. 107-120). Porto Alegre, RS: Artmed Editora.

Rodrigues, A. D. (2009). Do comprometimento de continuação ao entrincheiramento organizacional: o percurso de validação da escala e análise da sobreposição entre os construtos. Salvador, BA: UFBA.

Rots, I., Aelterman, A., Vlerick, P., \& Vermeulen, K. (2007). Teacher education, graduates' teaching commitment and entrance into the teaching profession. Teaching and Teacher education, 23(5), 543-556.

Salami, S. O. (2007). Relationships of emotional intelligence and self-efficacy to work attitudes among secondary school teachers in southwestern Nigeria. Essays in Education, 20(1), 43-56.

Schwarzer, R. (Ed.). (2014). Self-efficacy: Thought control of action. Taylor \& Francis.

Schwarzer, R., \& Hallum, S. (2008). Perceived teacher self-efficacy as a predictor of job stress and burnout: Mediation analyses. Applied psychology, 57, 152-171.

Shinyashiki, R. T. (2006). A influência da auto-eficácia dos gestores na administração de crises (Doctoral dissertation, Universidade de São Paulo), São Paulo, SP: USP.

Silva, E. C., \& Bastos, A. V. B. (2010). A escala de consentimento organizacional: construção e evidências de sua validade. Revista Psicologia: Organizações e Trabalho, 10(1), 7-22.

Silva, E. E. C. (2009). Consentimento organizacional: uma proposta de medida do construto (Dissertation, Universidade Federal da Bahia), Salvador, BA: UFBA.

Silva, E. E. C.; Bastos, A. V. B. (2015). Consentimento Organizacional. In Puente-Palacios, K.; Peixoto, A. L. A, Ferramentas de diagnóstico para organizações e trabalho: um olhar a partir da psicologia (pp. 92-106). Porto Alegre, RS: Artmed.

Smith, P. A., \& Yung, W. (2019). A review and evaluation of the use of longitudinal approaches in business surveys. Longitudinal and Life Course Studies, 10(4), 491-511.

Solinger, O. N., Van Olffen, W., Roe, R. A., \& Hofmans, J. (2013). On becoming (un)committed: A taxonomy and test of newcomer onboarding scenarios. Organization Science, 24(6), 16401661.

Soria, M. S., \& Martínez, I. M. M. (2006). Autoeficacia en el trabajo: el poder de creer que tú puedes. Estudios financieros. Revista de trabajo y seguridad social: Comentarios, casos prácticos: recursos humanos, (279), 175-202.

Stajkovic, A. D., \& Luthans, F. (1998). Self-efficacy and work-related performance: A meta-analysis. Psychological bulletin, 124(2), 240-261.

Tsai, M. T., Tsai, C. L., \& Wang, Y. C. (2011). A study on the relationship between leadership style, emotional intelligence, self-efficacy and organizational commitment: A case study of the Banking Industry in Taiwan. African Journal of Business Management, 5(13), 5319-5329. 
Vohra, N. (2009). Influence of positive characteristics on organizational commitment and job satisfaction of Indian middle managers. In Working Paper Series Indian Institute of Management Calcutta (pp. 1-32). Calcutta: IIMC.

Wood, R., \& Bandura, A. (1989). Social cognitive theory of organizational management. Academy of management Review, 14(3), 361-384.

Yousaf, A., \& Sanders, K. (2012). The role of job satisfaction and self-efficacy as mediating mechanisms in the employability and affective organizational commitment relationship: a case from a Pakistani university. Thunderbird International Business Review, 54(6), 907-919.

Zee, M., \& Koomen, H. M. (2016). Teacher self-efficacy and its effects on classroom processes, student academic adjustment, and teacher well-being: A synthesis of 40 years of research. Review of Educational research, 86(4), 981-1015.

Zimmerman, B. J. (2000). Self-efficacy: An essential motive to learn. Contemporary educational psychology, 25(1), 82-91.

\section{AUTHORS}

\section{Laércio André Gassen Balsan}

Institution: Universidade Federal de Santa Maria - UFSM, Santa Maria, RS, Brazil

He holds a degree in Administration from the Federal University of Santa Maria - UFSM, a degree in Physical Education from UFSM, a Master degree and a PhD in Administration from the Postgraduate Program in Administration at PPGA/UFSM.

E-mail: laerciobalsan@yahoo.com.br

ORCID: 0000-0003-4837-4741

\section{Antônio Virgílio Bittencourt Bastos}

Institution: Universidade Federal da Bahia - UFBA, Salvador, BA, Brazil

He holds a degree in Psychology from the Federal University of Bahia - UFBA, holds a Masters in Education from the Federal University of Bahia - UFBA and PhD in Psychology from University from Brasília - UNB. He is currently a full professor of Social Psychology of Organizations, at the Institute of Psychology of the Federal University of Bahia. He was a member of the Federal Council of Psychology, being president in 1986. He served as a member of the commission of specialists in teaching Psychology at MEC / SESu (1994-2000). He was a member of the CNPq Board of Psychology, the INEP Psychology Commission and the Psychology area committee at CAPES. He was Coordinator of the Psychology Area at CAPES between 2011-2018 and member, at INEP, of the Psychology Commission for ENADE. Researcher I-A of CNPq.

E-mail: antoniovirgiliobastos@gmail.com

ORCID: 0000-0002-1322-5749

\section{Vânia Medianeira Flores Costa}

Institution: Universidade Federal de Santa Maria - UFSM. Santa Maria, Rio Grande do Sul, Brazil. She holds a degree in Administration from the Federal University of Santa Maria - UFSM, holds a Masters in Administration from the Post-Graduate Program in Administration of Federal University of Santa Catarina - UFSC and PhD in Administration from the Post-Graduate Program in Administration of the Federal University of Bahia - UFBA. $\mathrm{He}$ is currently Adjunct Professor in the Administration area. She works as a Professor in the Postgraduate Program in Administration (PPGA/UFSM).

E-mail: vania.costa@ufsm.br

ORCID: 0000-0002-6099-820X 


\section{Marcus Vinicius Nascimento Schleder}

Institution: Universidade Federal de Santa Maria - UFSM, Santa Maria, Rio Grande do Sul, Brazil. He holds a degree in Business Administration from the Federal University of Santa Maria (UFSM). He is currently pursuing a specialization in Auditing and Controllership from the Franciscan University (UFN) and pursuing a Master degree in Administration from the Postgraduate Program in Administration at PPGA / UFSM.

E-mail: marcus.schleder@gmail.com

ORCID: 0000-0003-0952-4487

\section{Fernanda Binotto Vizzotto Balsan}

Institution: Universidade Federal de Santa Maria - UFSM. Santa Maria, Rio Grande do Sul, Brazil. She holds a degree in law from FADISMA and holds a degree in physical education from Santa Maria's Federal University (Universidade Federal de Santa Maria - UFSM).

E-mail: fevizzotto@yahoo.com.br

ORCID: 0000-0002-8194-4884

\section{Contribution of authors:}

Every author should account for at least one component of the work. Paper approved for publication need to specify the contribution of every single author.

\begin{tabular}{|c|c|c|c|c|c|}
\hline Contribution & [Author 1] & [Author 2] & [Author 3] & [Author 4] & [Author 5] \\
\hline 1. Definition of research problem & $\sqrt{ }$ & $\sqrt{ }$ & $\sqrt{ }$ & & \\
\hline $\begin{array}{l}\text { 2. Development of hypotheses } \\
\text { or research questions (empirical } \\
\text { studies) }\end{array}$ & $\sqrt{ }$ & $\sqrt{ }$ & $\sqrt{ }$ & & \\
\hline $\begin{array}{l}\text { 3. Development of theoretical } \\
\text { propositions } \\
\text { (theoretical work) }\end{array}$ & $\sqrt{ }$ & $\sqrt{ }$ & $\sqrt{ }$ & & \\
\hline $\begin{array}{l}\text { 4. Theoretical foundation / Litera- } \\
\text { ture review }\end{array}$ & $\sqrt{ }$ & $\sqrt{ }$ & $\sqrt{ }$ & & \\
\hline $\begin{array}{l}\text { 5. Definition of methodological } \\
\text { procedures }\end{array}$ & $\sqrt{ }$ & $\sqrt{ }$ & $\sqrt{ }$ & & \\
\hline 6. Data collection & $\sqrt{ }$ & & & $\sqrt{ }$ & $\sqrt{ }$ \\
\hline 7. Statistical analysis & $\sqrt{ }$ & $\sqrt{ }$ & $\sqrt{ }$ & & \\
\hline $\begin{array}{l}\text { 8. Analysis and interpretation of } \\
\text { data }\end{array}$ & $\sqrt{ }$ & $\sqrt{ }$ & $\sqrt{ }$ & $\sqrt{ }$ & $\sqrt{ }$ \\
\hline $\begin{array}{l}\text { 9. Critical revision of the manu- } \\
\text { script }\end{array}$ & V & $\sqrt{ }$ & $\checkmark$ & $\sqrt{ }$ & $\sqrt{ }$ \\
\hline 10. Manuscript writing & $\sqrt{ }$ & & & $\sqrt{ }$ & $\sqrt{ }$ \\
\hline $\begin{array}{l}\text { 11. Translation and grammar } \\
\text { proofing }\end{array}$ & $\sqrt{ }$ & & & $\sqrt{ }$ & $\sqrt{ }$ \\
\hline
\end{tabular}

\section{Conflict of Interest}

The authors have stated that there is no conflict of interest.

\section{Copyrights}

ReA/UFSM owns the copyright to this content.

Plagiarism Check

The ReA/UFSM maintains the practice of submitting all documents approved for publication to the plagiarism check, using specific tools, e.g.: CopySpider. 